\title{
Developing Students' Responsibility Character in Mathematics Teaching and Learning through Problem-Based Learning
}

\author{
Chairil Faif Pasani \\ Universitas Lambung Mangkurat \\ Banjarmasin, Indonesia \\ chfaifp@unlam.ac.id
}

\begin{abstract}
One of the characters that affect students' success is responsibility. If responsibility is ignored, it will harm the students themselves or others. Therefore, we need a proper learning model to develop students' responsibility. ProblemBased Learning (PBL) is a model that is used to make students become more responsible. The purpose of this study was to develop the character of the students' responsibility through PBL model. This study was designed and implemented using a quasiexperimental design with equivalent time series. The subjects of this research were the junior high school students. The object of the research is the whole process and the results of the PBL model in mathematics to develop students' responsibility character. The data were collected through documentation, observations, and tests. The data were analyzed using repeated measures of ANOVA and regression test. The results showed that PBL model can improve students' learning outcomes and develop the students' responsibility character. It was marked by an increase in the percentage of the value of the character qualifications of the students' responsibility. In addition, there was an increase in the average value of the students' learning outcomes.
\end{abstract}

Keywords—responsibility character, problem-based learning

\section{INTRODUCTION}

Responsibility is a person's attitude and behavior to carry out any duties and obligations that he/she should do to himself/herself, community, environment (natural, social, and cultural), country and God Almighty [1]. Therefore, responsibility is a character that must be inculcated in ourselves and in social life, because if it is left, it will harm the people themselves or other people. The teaching and learning process in the classroom by subject matter teachers is concrete activities that can become character education media. One of the subjects which can be the character education media is mathematics. Reference [2] also explains that the characters that can be developed in mathematics including curiosity, creativity, responsibility, and hard work.

Previous studies by [3][4][5] and [6] have brought positive results on students understanding, thinking skill, cognitive load perspective, and motivation in the Science and mathematics concept using Problem-Based Learning (PBL) model. It is then, in terms of character education, students' responsibility character development is also believed to develop using one suitable model namely PBL model. PBL itself is defined as the learning gained through the process towards an understanding of problem's resolution. The problem was first met in the learning [7]. Its relation to the responsibility character is that PBL helps students for finding out the information for themselves [8]. Besides, PBL is a learning approach that has been constructed to consider a whole range of theories. In particular, the stages of the PBL implementation are divided into five [9], namely:

- Students' orientation

- Organizing the students

- Guiding the inquiry of both individuals and groups

- Developing and presenting the results

- Analyzing and evaluating the process and problemsolving results.

PBL will be effective and efficient if a teacher or educator has certain expectations as follows:

- Teachers expect the students to not merely remember the lessons, but also understand and master the lesson thoroughly.

- Teachers intend to develop students' rational thinking skill that is the ability to analyze situations, apply their knowledge in new situations, know the difference between fact and opinion, as well as develop the ability to make an objective judgment.

- Teachers expect the students' ability to solve problems and create their intellectual challenge.

- Teachers encourage students to be more responsible for their learning.

- Teachers expect students to able to understand the relationship between what is learned with the reality of their life.

When the teacher plays a role as a facilitator, he/she can help students stimulate both non-verbal and verbal strategies. Particularly on responsibility character, it is seen on the verbal strategies when the teacher returns and deflects questions by responses, "Well, what do you think?" or "What do other people think" as the students ask questions to him/her [8]. This, then, stimulates students to take the responsibility of what they just acted rather than directly spoon-feed them. 
Their mental effort is lowered indirectly through the learning. On their research, Reference [10] involved the mental effort on the Example-Problem-Based Learning (EPBL) and the result proved that it leads to better test performance with less mental effort invested during learning, as well as more efficient learning. However, both with or without the teacher as a facilitator does not influence the results of its efficiency in terms of knowledge, critical thinking skills, motivation and group dynamic [11]. This also indicates that students are able to take responsibility as they go through the learning.

As there is not any wider study on responsibility character in mathematics teaching and learning through Problem-Based Learning, this present study was conducted to fill in the gap by examining the development of students' responsibility character in mathematics teaching and learning through PBL. The three foci of this research are whether or not PBL learning model can develop students' responsibility character, whether or not PBL model can improve student learning outcomes, whether or not there is a relationship between the students' responsibility and the learning outcomes.

Based on the adaptation from [1], further, the following are some indicators that will serve as guidelines for responsibility character assessment:

- Completing all tasks and exercises that become their responsibility.

- Carrying out the instruction well during the learning process.

- Being cooperative.

- Completing the work according to the determined time.

- Being serious about doing something.

- Being diligent and industrious during the learning process.

- Helping a friend who has difficulty in learning.

- Providing or proposing solutions to problems.

\section{METHODS}

The employed method in this study was a quasiexperimental method with Equivalent Time Series design in Fig. 1 below.

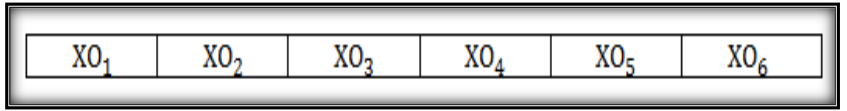

Fig. 1. Equivalent Time Series

$\mathrm{X}$ represents the treatment (PBL learning model, was repeated up to six times) and $\mathrm{O}$ states the measurement results (in design, the measurement was repeated up to six times).Fostering students' responsibility character required three stages of implementation, namely knowing, improving and developing. Based on the abovementioned design, $\mathrm{O}_{1}$ and $\mathrm{O}_{2}$ were the stages to know the student's responsibility character, $\mathrm{O}_{3}$ and $\mathrm{O}_{4}$ were the stages to improve, while $\mathrm{O}_{5}$ and $\mathrm{O}_{6}$ were the stages to develop the students' responsibility character.
The subjects of this study were all students of class VII SMPN 26 Banjarmasin in the academic year 2015/2016.Data collection techniques in this study were documentation, observation, and tests. The data were obtained from students' responsibility character based on the observation and students' learning outcome drawn from the results of the written test. Students' responsibility character values were obtained every meeting and were analyzed by comparing the development of the students' responsibility character values. Meanwhile, the students' learning outcomes of each stage of the implementation (knowing, improving and developing) were averaged in advance. The knowing stage score was the average score of meeting I and II, the improving stage was the average score of meetings III and IV, and the developing stage score was the average score meetings $\mathrm{V}$ and VI.

Having obtained the score of each stage, the further analysis used SPSS version 21.0 software by the following steps:

- The average data analysis using the repeated measure of ANOVA.

- The correlation analysis to scrutinize the relationship between the responsibility character and students learning outcomes.

- The final step was to use the regression analysis to scrutinize how much of the responsibility character affects students learning outcomes.

Students' responsibility character observation was done by giving a score of 1 to 5 to each indicator shown by the students. The used scoring guidelines were in accordance with the criteria in TABLE I [12].

TABLE I. THE CRITERIA OF RESPONSIBILITY INDICATOR SCORES

\begin{tabular}{|l|l|}
\hline \multicolumn{1}{|c|}{ Score } & \multicolumn{1}{c|}{ Behavior } \\
\hline $1=$ very poor & $\begin{array}{l}\text { When the student has not demonstrated early signs } \\
\text { of behavior as stated in the indicator. }\end{array}$ \\
\hline $3=$ fairly & $\begin{array}{l}\text { When the students have begun showing early signs } \\
\text { of behavior as expressed in the indicators but have } \\
\text { not been consistent. }\end{array}$ \\
\hline $4=$ good & $\begin{array}{l}\text { When the students have already shown various signs } \\
\text { of behavior as stated in the indicators and started to } \\
\text { be consistent. }\end{array}$ \\
\hline $5=$ very good & $\begin{array}{l}\text { When the students have often exhibited behavior as } \\
\text { stated in the indicators consistently. }\end{array}$ \\
\hline & $\begin{array}{l}\text { When the students continuously have demonstrated } \\
\text { appropriate behavior expressed in indicators } \\
\text { consistently. }\end{array}$ \\
\hline
\end{tabular}

The scores of these criteria were then used as the score of the students' responsibility to be calculated with the following conditions. To view the students' responsibility category [12], the obtained scores were confirmed as shown in TABLE II below:

TABLE II.THE CATEGORY OF RESPONSIBILITY CHARACTER

\begin{tabular}{|c|c|}
\hline Scores & Category \\
\hline
\end{tabular}




\begin{tabular}{|c|c|}
\hline $81.00-100.00$ & Have become habit \\
\hline $61.00-80.99$ & Already developed \\
\hline $41.00-60.99$ & Start Developing \\
\hline $21.00-40.99$ & Start Being Seen \\
\hline 0 to 20.99 & Have not be seen \\
\hline
\end{tabular}

The scoring system of the individual student's learning outcome uses the formula:

$$
\mathrm{N}=\frac{\text { obtained score }}{\text { maximum score }} \times 100
$$

Note: $\mathrm{N}=$ final grade .

The results of the obtained scores classification can be changed into percentage form by using the formula, namely:

$$
\mathrm{P}=\frac{f}{\mathrm{~N}} \times 100 \%
$$

with:

$f=$ frequency of the scores being the percentage,

$\mathrm{N}=$ Number of the Class (number of the students),

$\mathrm{P}=$ the percentage.

Qualification of learning outcomes achieved by the students can be seen through the average score. The average score obtained is then interpreted using the criteria in Table III below:

TABLE III. STUDENTS' LEARNING OUTCOMES QUALIFICATION

\begin{tabular}{|c|c|c|}
\hline No. & Score & Qualification \\
\hline 1 & $\geq 95$ & Excellent \\
\hline 2 & $80-94.99$ & Very good \\
\hline 3 & $65-79.99$ & Good \\
\hline 4 & $55-64.99$ & Fair \\
\hline 5 & $40-54.99$ & Poor \\
\hline 6 & 40 & Very poor \\
\hline
\end{tabular}

After normality test was done, the next stage was computing a difference test. The difference test was performed to determine whether there were significant differences between the students' learning outcomes thoroughly.

\section{RESULTS AND DISCUSSION}

The responsibility character score was the score obtained by using the provided observation sheet. TABLE IV below shows the responsibility score distribution at each meeting.

TABLE IV. DISTRIBUTION FREQUENCY OF THE STUDENTS' RESPONSIBILITY CHARACTER SCORE

\begin{tabular}{|c|c|c|c|c|c|c|c|}
\hline \multirow{2}{*}{ Score } & \multirow{2}{*}{$\begin{array}{c}\text { Catego } \\
\text { ry }\end{array}$} & \multicolumn{7}{|c|}{ Meeting } \\
\cline { 3 - 8 } & & & & & & & \\
\hline $\begin{array}{c}81.00 \text { to } \\
100.00\end{array}$ & HBH & 0 & 0 & 0 & 0 & 0 & 7 \\
\hline 61 to 80.99 & $\mathrm{AD}$ & 0 & 0 & 0 & 9 & 20 & 25 \\
\hline 41.00 to 60.99 & $\mathrm{SD}$ & 3 & 6 & 23 & 20 & 13 & 2 \\
\hline 21.00 to 40.99 & $\mathrm{SBS}$ & 30 & 28 & 9 & 5 & 1 & 0 \\
\hline 0 to 20.99 & HNBS & 1 & 0 & 0 & 0 & 0 & 0 \\
\hline \multicolumn{2}{|c|}{ Number of the students } & 34 & 34 & 34 & 34 & 34 & 34 \\
\hline
\end{tabular}

Notes:

$f \quad=$ Frequency / number of the students

$\mathrm{HBH}=$ Have Become Habit

$\mathrm{AD} \quad=$ Already Developed

SD $\quad=$ Start Developing

SBS =Start Being Seen

HNBS = Have Not Be Seen

In this present study, we sought for the students' responsibility character development in mathematics teaching and learning through PBL. From the table above, it is seen that there is an increase in the number of students in the low category into a better category. Based on these data there is an increase in the students' responsibility character into more categories. The results present that PBL learning model emphasizes the students to work together to solve problems. This result is in line with [13] who showed that the students are actively learning and they can gain the knowledge through a collaborative learning situation within the group. It is also emphasized by [8] that in problem-based learning, the students both are on the path of thinking for themselves and taking the responsibility for teaching their friends in the teams because they are teammates. One of the essential parts of this approach is the students are adequately prepared to complete their assigned tasks successfully.

However, in regard to the teacher, there is a different view on the facilitator role. As reference [11] claimed that the facilitator existence is not a big deal, reference [8] mentioned that "it is deemed the tutor's responsibility to take the time to teach students to be successful team members". Despite this view, when working together, students realized that doing a job would be easier if it was done together. If there was one or were several students who did not cooperate, it would make the group's work slower in solving the problem. It makes students realize the importance of their responsibility as members of the group. They also learn the subject, take responsibility for their learning and long life learning (Tseng, Chiang, \& Hsu, 2008) in [14]. All in all, all these evidence proved that by using PBL model, students can foster their responsibility.

Then, for the different test, the employed analysis was repeated measures of ANOVA. 
TABLE V. THE AVERAGE LEARNING OUTCOMES EVERY STAGE

\begin{tabular}{|c|c|c|c|}
\hline & Mean & Std. deviation & N \\
\hline Knowing Stage & 73.2464668 & 7.09085656 & 34 \\
\hline Improving Stage & 76.8814879 & 7.79857480 & 34 \\
\hline Developing Stage & 82.3508815 & 6.28418561 & 34 \\
\hline
\end{tabular}

From the above table, it can be seen that there was an increase in the average of student learning outcomes although, in fact, the individual student learning outcomes did not necessarily increase due to the material difference in each measurement.

TABLE VI. THE SIGNIFICANCE OFONE WAY ANOVA RESULTS

\begin{tabular}{|c|c|c|c|c|c|c|}
\hline \multicolumn{7}{|c|}{ Tests of Within-Subjects Effects } \\
\hline \multicolumn{7}{|c|}{ Measure: Students } \\
\hline \multicolumn{2}{|c|}{ Source } & $\begin{array}{c}\text { Type III Sum of } \\
\text { Squares }\end{array}$ & df & $\begin{array}{c}\text { mean } \\
\text { Square }\end{array}$ & $\mathbf{F}$ & Sig. \\
\hline \multirow{4}{*}{$\begin{array}{l}\text { Learning } \\
\text { outcomes }\end{array}$} & \begin{tabular}{|c|} 
Assumed \\
Sphericity \\
\end{tabular} & 1428.204 & 2 & 714.102 & 35.126 &, 000 \\
\hline & \begin{tabular}{|c|} 
Greenhouse \\
-Geisser
\end{tabular} & 1428.204 & 1,977 & 722.482 & 35.126 &, 000 \\
\hline & $\begin{array}{l}\text { Huynh- } \\
\text { Feldt }\end{array}$ & 1428.204 & 2,000 & 714.102 & 35.126 &, 000 \\
\hline & $\begin{array}{l}\text { Lower- } \\
\text { bound }\end{array}$ & 1428.204 & 1,000 & 1428.204 & 35.126 &, 000 \\
\hline \multirow{4}{*}{$\begin{array}{c}\text { Error } \\
\text { (Learning } \\
\text { outcomes } \\
\text { ) }\end{array}$} & \begin{tabular}{|c|} 
Assumed \\
Sphericity
\end{tabular} & 1341.778 & 66 & 20.330 & & \\
\hline & \begin{tabular}{|c} 
Greenhouse \\
-Geisser
\end{tabular} & 1341.778 & $\begin{array}{r}65.23 \\
4 \\
\end{array}$ & 20.569 & & \\
\hline & $\begin{array}{l}\text { Huynh- } \\
\text { Feldt }\end{array}$ & 1341.778 & $\begin{array}{r}66,00 \\
0\end{array}$ & 20.330 & & \\
\hline & $\begin{array}{l}\text { Lower- } \\
\text { bound }\end{array}$ & 1341.778 & $\begin{array}{r}33,00 \\
0 \\
\end{array}$ & 40.660 & & \\
\hline
\end{tabular}

It is seen that there is 0 on Greenhouse-Geisser (smaller than $\alpha=0.05$ ), which means that there were differences in the average score significantly between each stage.

\section{TABLE VII. THE RESULTS ON EACH STAGE MEASURE: LEARNING} OUTCOMES

\begin{tabular}{|c|r|r|r|r|r|r|}
\hline $\begin{array}{c}\text { Evaluati } \\
\text { on } \\
\text { Result }\end{array}$ & $\begin{array}{c}\text { (J) } \\
\text { Evaluation } \\
\text { Results }\end{array}$ & $\begin{array}{c}\text { Mean } \\
\text { Differe } \\
\text { nce (IJ) }\end{array}$ & $\begin{array}{c}\text { Std. } \\
\text { Error }\end{array}$ & Sig. ${ }^{\text {b }}$ & \multicolumn{2}{|c|}{$\begin{array}{c}\text { 95\% Confidence } \\
\text { Interval for } \\
\text { Difference }\end{array}$} \\
\cline { 4 - 8 } & & & & \multicolumn{2}{|c|}{$\begin{array}{c}\text { Lower } \\
\text { Bound }\end{array}$} & $\begin{array}{c}\text { Upper } \\
\text { Bound }\end{array}$ \\
\hline \multirow{2}{*}{1} & $-3.635^{*}$ & 1,133 & .009 & -6.492 &,- 778 & $-3.635^{*}$ \\
\cline { 2 - 7 } & $-9.104^{*}$ & 1,111 &, 000 & -11.907 & -6.302 & $-9.104^{*}$ \\
\hline \multirow{2}{*}{2} & $3.635^{*}$ & 1,133 & .009 &, 778 & 6.492 & $3.635^{*}$ \\
\cline { 2 - 7 } & $-5.469^{*}$ & 1.034 &, 000 & -8.078 & -2.861 & $-5.469^{*}$ \\
\hline \multirow{2}{*}{3} & $9.104^{*}$ & 1,111 &, 000 & 6.302 & 11.907 & $9.104^{*}$ \\
\cline { 2 - 7 } & $5.469^{*}$ & 1.034 &, 000 & 2.861 & 8.078 & $5.469^{*}$ \\
\hline
\end{tabular}

From the table above, it can be seen that the average difference between measurement 1 (knowing the stage learning outcomes) and measurement 2 (improving stage of responsibility character) was 3.635 and the significance value was 0.009. Due to the significance value smaller than $\alpha=$ 0.05 , it can be concluded that there were differences in the average significant difference between the value of students' learning outcomes and the improving stage.

The difference between average measurement1 (knowing the stage of the responsibility character) and the average of measurement 3 (developing stage of responsibility character) was 9.104 and the obtained significance value was 0 . Since this significance value was also smaller than $\alpha=0.05$, it can be concluded that there were differences between the students learning outcomes score on the developing stage.

Meanwhile, the difference between the average measurement 2 (improving stage of responsibility character) and the average measurement 3 (developing stage of responsibility character) was 5.469 and the significance value was 0 (smaller than $\alpha=0.05$ ), it can be concluded that there were significant differences between the students learning outcomes score and the developing stage.

This positive result enriches the previous study by [6] on their investigation focusing on primary school teachers. Meanwhile, this study had students as the subjects. This significant result makes PBL to be more convincing to be used in the classroom. Reference [8] claimed that much of the learning focuses on predictable outcomes. As any other learning model, PBL is worth to apply as it not only benefits students with the knowledge but also helps students to see that learning and life take place in contexts where they are taught to be responsible. This is a significant contribution that students finally create better work habits toward their experience in learning as well as build attitudes in the learning itself [6]. Thus, a notion of applying PBL to improve students' learning outcomes has been acknowledged. Mathematics teachers can go get two important things at the same time, teaching and educate students to be better people during their study and ahead.

Then, to scrutinize the relationship between the students' responsibility character and the learning outcomes, the test with SPSS acquired the correlation as many as 0.647 which is included in the category of a strong relationship. It means the students' responsibility character was positively associated with the learning outcomes. The higher the score of responsibility character, the higher the learning outcomes are.

Finally, by looking at the relationship between the responsibility character and the learning outcomes it can be created the regression models, namely: $\widehat{Y}=0,347 \mathrm{X}+$ 59,886 . It means every increase of one point of the responsibility character, there will be an increase of 0.347 points of the learning outcomes.

According to [8], two first of the many problem-based learning courses characteristics based on Boud are: (1) an acknowledgment of the base of experience of learners and (2) an emphasis on students taking responsibility for their own learning. It indicates that this third research finding is marked on the PBL characteristics that they come one another. Another support of the results is shown by some examples of a 
team learning contract. Reference [8] establishes that "students who work in the team will (1) commit to its membership to encourage sharing of information, (2) create a safe and supportive learning context, (3) give and receive supportive feedback towards one another, (4) produce agreed work on time, (5) seek to clarify, and contribute to, the definition of the role of the facilitator in the team, (6) take shared responsibility for the progress of the process and outcomes of the team, and (7) share knowledge with and learn from other members of their team. "It is clearly seen that students' responsibility character and learning outcomes come along in the PBL model applied in the classroom. Therefore, there is an intertwined relationship between students' responsibility character and their learning outcome. As has been stated by [13] PBL model, then, can become an appropriate tool in teaching Mathematics and developing students' responsibility character.

\section{CONCLUSION}

In a nutshell, this current study brought some points that first PBL learning model can develop students' responsibility character. It was marked by an increase in the students' responsibility character score into a better category. Second, PBL model can improve student learning outcomes. It was marked by increasing average learning outcomes into higher qualifications. Third, there is a relationship between the students' responsibility and the learning outcomes to which categorized in a strong relationship category. This research brings an insight that teachers who would like to develop students' responsibility character in mathematics teaching and learning are suggested to use problem-based learning model in their teaching.

\section{REFERENCES}

[1] A. W. D. D. Warso, Proses pembelajaran dan penilaiannya di SD/MI/SMP/MTs/SMA/SMK. Yogyakarta: Graha Cendikia, 2014.
[2] E. Sulistyowati, Implementasi Kurikulum Pendidikan Karakter. Yogyakarta: Citra Aji Parama, 2012.

[3] G. Gorghiu, L. M. Draghicescu, S. Cristea, A. Petrescu, and L. M. Gorghiu, "Problem-based learning - an efficient learning strategy in the science lessons context", in Procedia - Social and Behavioral Sciences, vol. 191. pp. $1865-1870$.

[4] R. A. Tarmizi and S. Bayat, "Collaborative problem-based learning in mathematics: a cognitive load perspective", in Procedia - Social and Behavioral Sciences, vol. 32. pp. 344-350.

[5] N. F. Harun, K. M. Yusof, M. Z. Jamaludin, and S. A.H. S. Hassan, "Motivation in problem-based learning implementation", in Procedia Social and Behavioral Sciences, vol. 56. pp. 233-242.

[6] A. A. Ari and Y. Katranci, "The opinions of primary mathematics student-teachers on problem-based learning method", in Procedia Social and Behavioral Sciences, vol. 116. pp. 1826-1831.

[7] M. Huda, Model-model pengajaran dan pembelajaran. Yogyakarta: PustakaPelajar, 2014.

[8] M. Savin-Baden and C. H. Major, Foundations of problem-based learning. New York, NY: Society for Research into Higher-Education \& Open University Press, 2004.

[9] Trianto, Model-model pembelajaran inovatif berorientasi konstruksivisme. Jakarta: Prestasi Pustaka, 2007.

[10] N. H. Jalani and L. C. Sern, "Efficiency comparisons between exampleproblem-based learning and teacher-centered learning in the teaching of circuit theory", in Procedia - Social and Behavioral Sciences, vol. 204. pp. 153-163.

[11] T. Y. Chiuan, N. B. Rosly, M. Z. B. Zolkipli, N. W. Wei, M. A. B. B, Ahamed, N. A. B, Mustapha, and A. S. Z. Zakaria. "Problem-based learning: with or without facilitator?" in Procedia - Social and Behavioral Sciences, vol. 18. pp. 394-399. 2011.

[12] Supinah and I.T. Parmi, Pengembangan pendidikan budaya dan karakter bangsa melalui pembelajaran matematika di SD. Yogyakarta: Kemendiknas, 2011.

[13] J. O. Fatokun and K. V. F. Fatokun, "A problem-based learning (PBL) application for the teaching of mathematics and chemistry in higher schools and tertiary education: an integrative approach",in Educational Research and Reviews Academic Journals, vol. 8(11). pp. 663-667. Retrieved from http://www.academicjournals.org/article/article1379 761476_Fatokun\%20and\%20Fatokun.pdf, 2013.

[14] M. Demirel and M. Dagyar, "Effects of problem-based learning on attitude: a meta-analysis study", in Eurasia Journal of Mathematics, Science, \& Technology Education, vol. 12(8). pp. 2115-2137. 2016. 